\title{
Five new epothilone metabolites from Sorangium cellulosum strain So0157-2
}

\author{
Jidong Wang, Hui Zhang, Linping Ying, Chuanxi Wang, Nan Jiang, Yue Zhou, Haibin Wang and Hua Bai \\ With the aim of identifying more novel natural epothilone derivatives produced by the epothilones $A$ and $B$ producing strain \\ Sorangium cellulosum strain So0157-2, a large-scale fermentation (5000 I) of the strain was carried out. As a result, five \\ new epothilone variants (1-5) were isolated from the fermentation broth. Their structures were established as 3- $\alpha-D-$ \\ arabinofuranosides of epothilones A (1), B (2), D (3), C (4) and 8-demethyl epothilone A (5) by extensive NMR analysis and \\ chemical methods. Bioassay results showed that compounds 1 and 2 had a weaker cytotoxic activity than did epothilone $B$. \\ The Journal of Antibiotics (2009) 62, 483-487; doi:10.1038/ja.2009.55; published online 3 July 2009
}

Keywords: cytotoxic activity; epothilone derivatives; Sorangium cellulosum

\section{INTRODUCTION}

Epothilones are naturally occurring 16-membered ring macrolides that constitute a novel class of antimicrotubule-targeting agents. As the major products, epothilones $\mathrm{A}$ and $\mathrm{B}$, were originally isolated from fermentations of the soil-derived myxobacterium Sorangium cellulosum So ce90, ${ }^{1-3}$ many natural epothilone analogs and related structures have been described. ${ }^{4-6}$ Moreover, synthetic and semisynthetic methods were important alternatives for obtaining epothilone analogs. At present, more epothilone variants are prepared in a synthetic manner. ${ }^{7,8}$ Of all the epothilones and other variants coming from natural resources and synthesis, ixabepilones have been approved by FDA in 2007 for clinical use for the treatment of certain forms of breast cancer, in addition to a number of them being in preclinical and clinical trials. ${ }^{9}$ The attractive potential of epothilones led us to search for more potent and selective epothilone derivatives to satisfy the needs of chemotherapy for tumors. Presumably, when fermentation was scaled up, there were some minor and new analogs that were not isolated in small-scale fermentation. Hence, we investigated the chemical compositions of large-scale fermentation (5000 l) of epothilones A and B producing strain S. cellulosum strain So0157-2, ${ }^{10}$ and five new epothilone variants (1-5, Figures 1 and 2) were obtained. Their structures were established as $3-\alpha$-D-arabinofuranosides of epothilones A (1), B (2), D (3), C 9 (4) and 8-demethyl epothilone A (5) by extensive NMR analysis and chemical methods. This paper describes the isolation and structure determination of the five new compounds and the cytotoxic activity of compounds $\mathbf{1}$ and $\mathbf{2}$.

\section{RESULTS AND DISCUSSION}

Structure elucidation

In the large-scale production and isolation of epothilones A and B from the strain S. cellulosum strain So0157-2, the byproducts, includ- ing other epothilones, were pooled and a crude extract was obtained. The pooling crude extract was isolated by silica gel column chromatography and semi-preparative HPLC to afford five new epothilone derivatives (1-5).

Compound 1 was isolated as a colorless oil. Its molecular formula of $\mathrm{C}_{31} \mathrm{H}_{47} \mathrm{NO}_{10} \mathrm{~S}$ was deduced from high-resolution electrospray ionization mass spectrometry (HRESIMS) $\mathrm{m} / z$ 648.2840 $\left([\mathrm{M}+\mathrm{Na}]^{+}\right.$, calcd 648.2818). The IR spectrum showed the hydroxyl absorption band at $3444 \mathrm{~cm}^{-1}$. The ${ }^{1} \mathrm{H}$ NMR spectrum of 1 showed two characteristic downfield singlet signals and one singlet methyl signal of epopthilones A and B at $\delta 7.26,6.55$ and 2.69, respectively. In addition to one vinyllic methyl at $\delta 2.07$, two aliphatic methyl doublets at $\delta 1.16$ and 1.03 and two aliphatic methyl singlets at $\delta 1.20$ and 1.32 were observed in the upfield. These data agreed well with those of epothilone A, except for a singlet proton signal at $\delta 5.12$ and five proton signals between $\delta 4.04$ and $\delta$ 3.60. The ${ }^{13} \mathrm{C}$ NMR and distortionless enhancement by polarization transfer 135 (DEPT 135) spectra of 1 exhibited 32 carbons. Except for five oxygenated carbons (one acetal carbon, three oxygenated methines and one oxygenated methylene), the chemical shifts of the remaining carbons were almost identical to that of epothilone A. By a detailed analysis of ${ }^{1} \mathrm{H}$ and ${ }^{13} \mathrm{C}$ NMR data and ${ }^{1} \mathrm{H}-{ }^{1} \mathrm{H}$ correlation spectroscopy $\left({ }^{1} \mathrm{H}_{-}{ }^{1} \mathrm{H}\right.$ COSY) and heteronuclear multiple bond correlation (HMBC) spectra, a furanose was connected to the anomeric carbon at $\delta$ 109.0. These data showed that compound 1 included two moieties, aglycone was epothilone A and sugar was a furanose. The connection position of sugar to aglycone epothilone A was confirmed by HMBC experiments. The crossing peak between $\delta 5.12$ (anomeric proton) and the $\delta 80.7$ (C-3) indicated that sugar connected to epothilone $\mathrm{A}$ by an ether bond between C-3 and C-1'. Thus, the gross planar structure of 1 was established. The attempt to perform acid hydrolysis of compound 1 to 


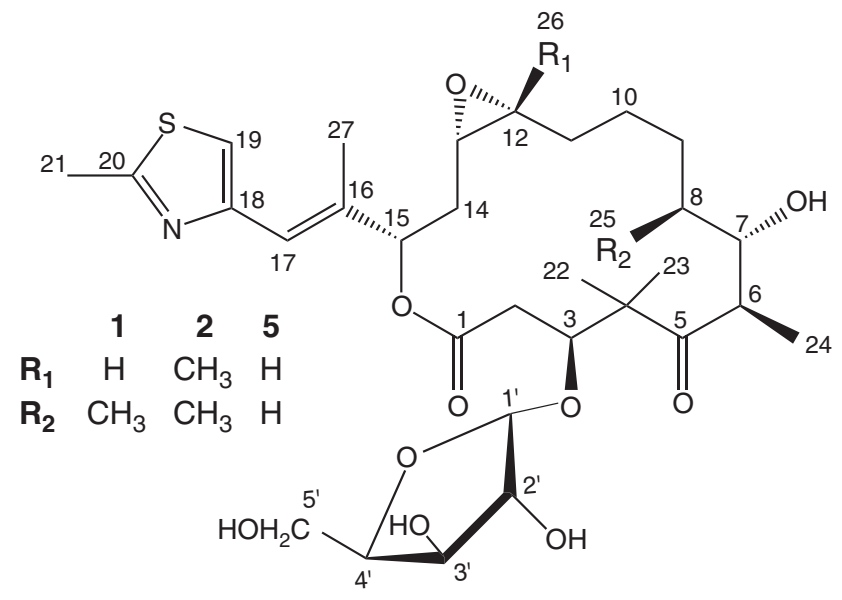

Figure 1 The structures of compounds 1, 2 and $\mathbf{5}$.

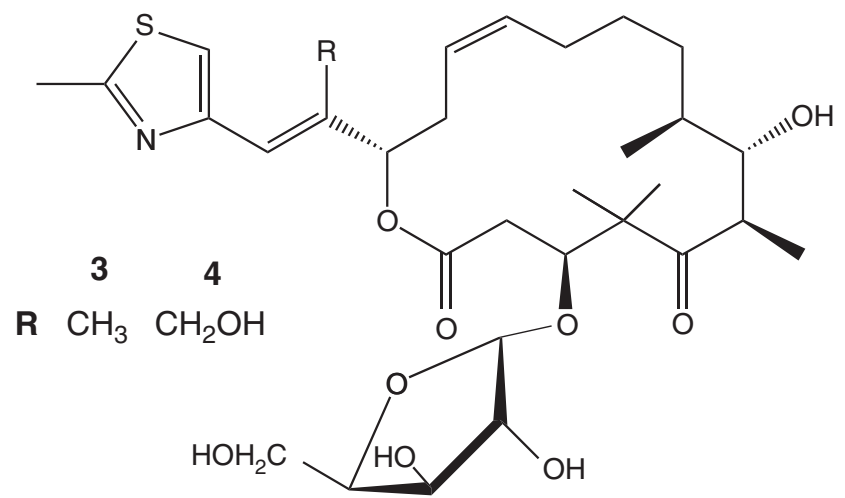

Figure 2 The structures of compounds $\mathbf{3}$ and $\mathbf{4}$.

obtain epothilone A was unsuccessful because of the instability of the three-membered ring between $\mathrm{C}-11$ and $\mathrm{C}-12$. By a detailed comparison of the ${ }^{1} \mathrm{H}$ and ${ }^{13} \mathrm{C}$ NMR data of 1 with those of epothilone $\mathrm{A}$ in conjunction with concurring with epothilone $\mathrm{A}$, the relative and absolute configuration of the aglycone of 1 was assigned as that of epothilone A.

Acid hydrolysis of $\mathbf{1}$ afforded an aglycone and a sugar, and the sugar component identified by co-chromatography with authentic samples of arabinose, ribose and xylose on TLC analysis, and the identical $R_{\mathrm{F}}$ values of the sugar moiety with those of arabinose indicated that the sugar moiety of $\mathbf{1}$ was arabinose. Absolute configuration for the arabinose was determined to be the $\mathrm{D}$ form according to the procedure developed by Tanaka et al. ${ }^{11}$ Comparison of the ${ }^{13} \mathrm{C}$ NMR data of the furanose moiety of 1 with that of methyl $\alpha$-D-arabinofuranoside and methyl $\beta$-D-arabinofuranoside reported in the literature, ${ }^{12}$ along with the small coupling constant $(J=1.2 \mathrm{~Hz})$ of the anomeric proton, assigned the configuration of the anomeric center (C-1') to be $\alpha$.

Compound 2 was obtained as a colorless oil. HRESIMS gave its molecular formula as $\mathrm{C}_{32} \mathrm{H}_{49} \mathrm{NO}_{10} \mathrm{~S}$. The ${ }^{1} \mathrm{H}$ and ${ }^{13} \mathrm{C}$ NMR data of 2 were similar to those of compound 1, except for the fact that a singlet methyl was present at $\delta 1.29$ in the ${ }^{1} \mathrm{H}$ NMR spectrum and an oxygenated quarternary carbon was present at $\delta 62.0$ in the ${ }^{13} \mathrm{C}$ NMR spectrum. Comparing the NMR data of the aglycone of $\mathbf{2}$ with those of epothilone B, the aglycone of $\mathbf{2}$ was very similar to epothilone B. Hence the aglycone of $\mathbf{2}$ was elucidated as epothilone B. The NMR data of sugar moiety were the same as those of $\mathbf{1}$ and were identified as $\alpha$-D-arabinofuranose. The linkage of the sugar moiety to epothilone B was confirmed by the HMBC correlations of $\delta 5.09$ (H-1') and $\delta 78.6(\mathrm{C}-3)$.

Compound 3 was isolated as a colorless oil. The molecular formula of 3 was determined to be $\mathrm{C}_{31} \mathrm{H}_{47} \mathrm{NO}_{9} \mathrm{~S}$ on the basis of HRESIMS analysis $\left[m / z 632.2895(\mathrm{M}+\mathrm{Na})^{+}\right]$and was supported by ${ }^{1} \mathrm{H}$ and ${ }^{13} \mathrm{C}$ NMR data (Tables 1 and 2). The numbers of carbon of 3 were the same as that of $\mathbf{1}$. The only difference in NMR spectra between $\mathbf{3}$ and $\mathbf{1}$ was that the three-membered ring of $\mathrm{C} 12-\mathrm{C} 13$ in 1 was replaced by a double bond in $\mathbf{3}$. Comparing the NMR data of the aglycone of $\mathbf{3}$ with those of epothilone $\mathrm{D}$, the aglycone of $\mathbf{3}$ was very similar to epothilone $\mathrm{D}$ and the aglycone of $\mathbf{3}$ was assigned to be epothilone $\mathrm{D}$. The sugar moiety of 3 was established as $\alpha$-D-arabinofuranose, similar to that of 1 . The connection of the aglycone and sugar moiety was also supported by the HMBC correlation of $\delta 5.19$ (H-1') and $\delta 79.4(\mathrm{C}-3)$.

Compound 4 was assigned the molecular formula of $\mathrm{C}_{31} \mathrm{H}_{47} \mathrm{NO}_{10} \mathrm{~S}$, similar to that of $\mathbf{1}$, on the basis of HRESIMS analysis $[\mathrm{m} / \mathrm{z} 648.2800$ $\left.(\mathrm{M}+\mathrm{Na})^{+}\right]$and NMR data (Tables 1 and 2). Analysis of the ${ }^{1} \mathrm{H}$ and ${ }^{13} \mathrm{C}$ NMR data for 4 revealed the presence of nearly identical structural features as those found in 3, except that the C-27 methyl in $\mathbf{3}$ was replaced by a hydroxylmethyl in 4 . This result was supported by the ${ }^{1} \mathrm{H}-{ }^{13} \mathrm{C}$ long-range correlations between $\delta_{\mathrm{H}} 6.61(\mathrm{H}-17)$ and $\delta_{\mathrm{C}} 58.3$ (C-27), $119.3(\mathrm{C}-19)$ and $79.6(\mathrm{C}-15)$, and between $\delta_{\mathrm{H}} 4.35(\mathrm{H}-27)$ and $\delta_{\mathrm{C}} 123.4(\mathrm{C}-17), 140.5(\mathrm{C}-16)$ and 79.6 (C-15). A comparison of the NMR data of the aglycone of 4 with those of epothilone $\mathrm{C}_{9}$ revealed the aglycone of 4 to be very similar to epothilone $C_{9}$ and hence the aglycone of $\mathbf{4}$ was assigned to be epothilone $C_{9}$. The sugar moiety of $\mathbf{4}$ was established as $\alpha$-D-arabinofuranose, similar to that of 1 . The connection of aglycone and sugar moiety was confirmed by the HMBC correlation of $\delta 5.18\left(\mathrm{H}^{-} 1^{\prime}\right)$ and $\delta 78.8(\mathrm{C}-3)$.

Compound 5 has a molecular formula of $\mathrm{C}_{30} \mathrm{H}_{45} \mathrm{NO}_{10} \mathrm{~S}$, consistent with a structure having one less methyl group than does 1 . Comparing the ${ }^{1} \mathrm{H}$ NMR data of $\mathbf{5}$ with that of $\mathbf{1}$, only a doublet methyl was found to be absent in 5 . The present $\mathrm{HMBC}$ correlation between $\delta_{\mathrm{H}} 1.03\left(\mathrm{H}_{3}-25\right)$ and $\delta_{\mathrm{C}} 78.7(\mathrm{C}-7)$ in 1 was not observed in 5 , and the ${ }^{1} \mathrm{H}-{ }^{1} \mathrm{H}$ COSY correlation of $\delta 3.85$ (H-7) and a methylene signal at $\delta 1.46$ and 1.60 $\left(\mathrm{H}_{2}-8\right)$ suggested that the $\mathrm{C}-25$ methyl in $\mathbf{1}$ was replaced by a hydrogen atom in $\mathbf{5}$. As a result, the aglycone of $\mathbf{5}$ was elucidated as 8-demethylepothilone $\mathrm{A}$ and the sugar moiety of $\mathbf{5}$ was established as $\alpha$-D-arabinofuranose, similar to that of 1 . The connection of aglycone of $\mathbf{5}$ and sugar moiety was supported by the HMBC correlation of $\delta 5.15\left(\mathrm{H}-1^{\prime}\right)$ and $\delta 78.5(\mathrm{C}-3)$. Thus, the structure of 5 was established.

\section{Biological activity}

Compounds $\mathbf{1}$ and $\mathbf{2}$ were evaluated for cytotoxic activity against two tumor cell lines by CCK- 8 methods, ${ }^{13}$ and the results showed that compounds $\mathbf{1}$ and $\mathbf{2}$ had a weaker cytotoxic activity than did epothilone B (Table 3).

Previous studies with regard to the structure-activity-relationship of various epothilone analogs had established that, in general, changes in the 16-membered macrolide framework led to a loss of tubulin affinity. For instance, sterechemical inversion ${ }^{14}$ and ring contraction/ expansion ${ }^{15}$ reduced tubulin-binding affinity. Specifically, the C-3 diastereomer (3R) of epothilone $\mathrm{A}$ had been reported to be inactive in both tubulin polymerization and cytotoxicity assays. ${ }^{16} \mathrm{~A}$ recent study showed that the 3-hydroxyl group may not be directly involved in the fundamental network of interactions between epothilones and b-tubulin. ${ }^{17}$ This suggested that the less potent of $\mathbf{1}$ and 2 , than epothilone $\mathrm{B}$, may be attributed to the change of conformation of the 
Table $1{ }^{1} \mathrm{H}$ NMR data for compounds $1-5$ ( 1 in $\mathrm{CD}_{3} \mathrm{OD}, 2-5$ in $\mathrm{CDCl}_{3}, J$ in $\mathrm{Hz}$ )

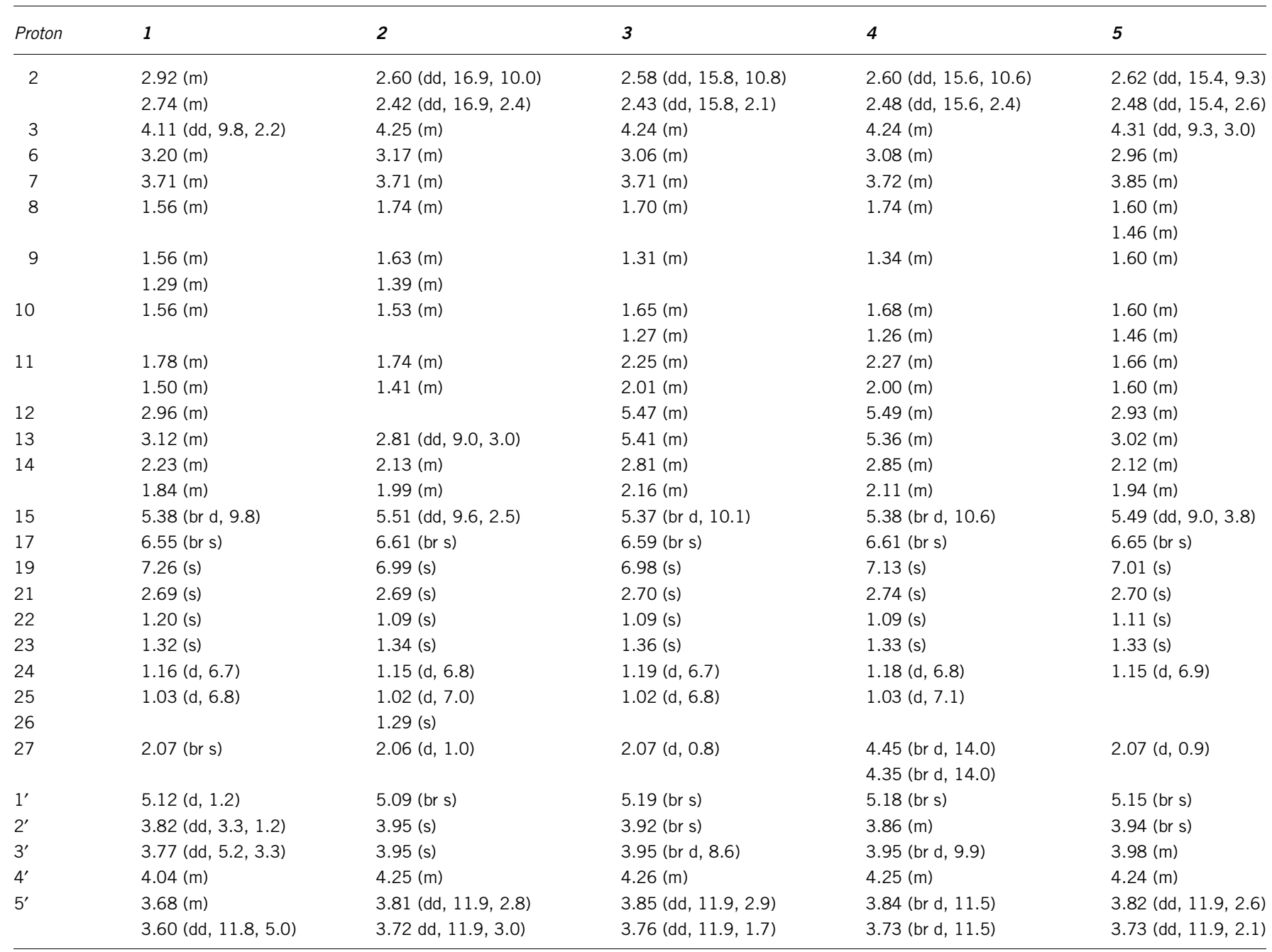

16-membered macrolide framework influenced by the 3- $\alpha$-D-arabinofuranoside moiety. Further work should be carried out to clarify the conformation of $\mathbf{1}$ and $\mathbf{2}$ and the structure-activity-relationship of C-3-substituted epothilones. Moreover, compounds 1-5 demonstrate the possibility of structure-activity-relationship being involved in the development of the second generation of epothilone.

\section{EXPERIMENTAL SECTION}

\section{General experimental procedures}

The UV spectra were obtained on a Varian CARY 300 BIO spectrophotometer (Varian Inc., Cary, NC, USA); IR spectra were recorded on a Nicolet Magna FTIR 750 spectrometer $\left(v_{\max }\right.$ in $\mathrm{cm}^{-1}$; Nicolet, Tokyo, Japan); ${ }^{1} \mathrm{H}$ and ${ }^{13} \mathrm{C}$ NMR spectra were measured with a Bruker DRX-400 $\left(400 \mathrm{MHz}\right.$ for ${ }^{1} \mathrm{H}$ and $100 \mathrm{MHz}$ for ${ }^{13} \mathrm{C}$; Bruker, Rheinstetten, Germany) spectrometer. Chemical shifts are reported in parts per million (p.p.m.) $(\delta)$, using residual $\mathrm{CHCl}_{3}\left(\delta_{\mathrm{H}}\right.$ 7.26 p.p.m.; $\left.\delta_{\mathrm{C}} 77.0\right)$ or $\mathrm{CD}_{3} \mathrm{OD}\left(\delta_{\mathrm{H}} 3.30\right.$ p.p.m.; $\left.\delta_{\mathrm{C}} 49.0\right)$ as an internal standard, with coupling constants $(J)$ in $\mathrm{Hz} .{ }^{1} \mathrm{H}$ and ${ }^{13} \mathrm{C}$ NMR assignments were supported by ${ }^{1} \mathrm{H}^{-1} \mathrm{H}$ COSY, heteronuclear multiple quantum correlation and $\mathrm{HMBC}$ experiments. Electrospray ionization mass spectrometry (ESIMS) and HRESIMS spectra were taken on a Q-TOF Micro LC-MS-MS mass spectrometer (Agilent Technologies UK Ltd., Manchester, UK). The analytic (Zorbax SB-C18, $5 \mu \mathrm{m}, 250 \times 4.6 \mathrm{~mm}$ i.d.) and semi-preparative (Zorbax SBC18, $5 \mu \mathrm{m}, 250 \times 9.4 \mathrm{~mm}$ i.d.) RP-HPLC was conducted on an Agilent 1100 series (Agilent Technologies Inc., Palo Alto, CA, USA). Commercial silica gel
(Qing Dao Hai Yang Chemical Group Co., Qingdao, Shandong, China; 100200 and 200-300 mesh) was used for column chromatography.

\section{Myxobacterium material}

The producing organism S. cellulosum strain So0157-2 was provided by Professor Yuezhong Li at the Shandong University, China and was deposited in the China Center of Typical Culture Collection (CCTCC) with accession no: CCTCC M 208078. Stock cultures were placed on a starch-yeast agar plate ( $0.8 \%$ soluble starch, $0.2 \%$ glucose, $0.2 \%$ peptone, $0.2 \%$ yeast extract, $0.2 \%$ $\mathrm{MgSO}_{4}, 0.1 \% \mathrm{CaCl}_{2}, \mathrm{pH} 7.8$ autoclave at $121{ }^{\circ} \mathrm{C}$ for $30 \mathrm{~min}$ ). Flask cultures were incubated at $30^{\circ} \mathrm{C}$ on a rotary shaker at 250 r.p.m. for 4 days. Fermentation was carried out in a 501 first seed fermentor (containing 301 fermentation broth), in a 5001 second seed fermentor (containing 3001 fermentation broth), and finally in a 50001 fermentor (containing 30001 fermentation broth) successively. The following production medium was used: $1.0 \%$ soluble starch, $0.4 \%$ glucose, $0.2 \%$ peptone, $0.2 \%$ yeast extract, $0.2 \% \mathrm{MgSO}_{4}, 0.1 \% \mathrm{CaCl}_{2}, \mathrm{pH}$ 7.8, autoclave. For the continuous adsorption of epothilones, $2.0 \%(\mathrm{v} / \mathrm{v})$ of XAD-1600 (Rohm and Haas, Paris, France) was added. Fermentation was carried out at $28^{\circ} \mathrm{C}$ for 12 days, stirring at 40 r.p.m. with an aeration rate of $120 \mathrm{~m}^{3}$ of air per hour.

\section{Extraction and isolation}

Adsorber resin (601) was separated from the 30001 fermentation broth with a process filter. After washing the resin with water, the resin was eluted with four 
Table $2{ }^{13} \mathrm{C}$ NMR and $\mathrm{HMBC}$ data for compounds $1-5$ (1 in $\mathrm{CD}_{3} \mathrm{OD}, 2-5$ in $\mathrm{CDCl}_{3}$ )

\begin{tabular}{|c|c|c|c|c|c|c|}
\hline Carbon & 1 & 2 & 3 & 4 & 5 & $H M B C(C \rightarrow H \#)$ \\
\hline 1 & $172.6 \mathrm{~s}$ & $170.1 \mathrm{~s}$ & $169.9 \mathrm{~s}$ & $170.3 \mathrm{~s}$ & $169.9 \mathrm{~s}$ & $2,3,15$ \\
\hline 2 & $39.2 \mathrm{t}$ & $39.0 \mathrm{t}$ & $39.0 \mathrm{t}$ & $38.8 \mathrm{t}$ & $38.8 \mathrm{t}$ & \\
\hline 4 & $53.6 \mathrm{~s}$ & $53.5 \mathrm{~s}$ & $53.3 \mathrm{~s}$ & $53.1 \mathrm{~s}$ & $53.2 \mathrm{~s}$ & \\
\hline 5 & $218.9 \mathrm{~s}$ & $218.9 \mathrm{~s}$ & $219.7 \mathrm{~s}$ & $219.7 \mathrm{~s}$ & $220.5 \mathrm{~s}$ & $3,22,23,24$ \\
\hline 6 & $47.7 \mathrm{~d}$ & $42.8 \mathrm{~d}$ & $42.2 \mathrm{~d}$ & $42.4 \mathrm{~d}$ & $44.4 \mathrm{~d}$ & 24 \\
\hline 9 & $31.7 \mathrm{t}$ & $31.0 \mathrm{t}$ & $32.2 \mathrm{t}$ & $32.3 t$ & $24.8 \mathrm{t}$ & \\
\hline 10 & $25.7 \mathrm{t}$ & $21.9 \mathrm{t}$ & $27.2 \mathrm{t}$ & $27.3 \mathrm{t}$ & $23.8 \mathrm{t}$ & \\
\hline 11 & $28.3 \mathrm{t}$ & $32.8 \mathrm{t}$ & $27.5 \mathrm{t}$ & $27.6 \mathrm{t}$ & $26.4 \mathrm{t}$ & \\
\hline 12 & $58.9 d$ & $62.0 \mathrm{~s}$ & $133.7 \mathrm{~d}$ & $134.0 \mathrm{~s}$ & $57.1 \mathrm{~d}$ & \\
\hline 13 & $56.5 \mathrm{~d}$ & $61.8 \mathrm{~d}$ & $124.6 \mathrm{~d}$ & $124.4 \mathrm{~d}$ & $54.4 \mathrm{~d}$ & \\
\hline 14 & $33.8 \mathrm{t}$ & $32.9 \mathrm{t}$ & $31.6 \mathrm{t}$ & $32.1 \mathrm{t}$ & $32.2 \mathrm{t}$ & \\
\hline 19 & $118.0 \mathrm{~d}$ & $117.0 \mathrm{~d}$ & $116.6 \mathrm{~d}$ & $119.3 d$ & $116.9 \mathrm{~d}$ & 17 \\
\hline 20 & $167.1 \mathrm{~s}$ & $166.3 \mathrm{~s}$ & $166.2 \mathrm{~s}$ & $167.3 \mathrm{~s}$ & $166.2 \mathrm{~s}$ & 21 \\
\hline 21 & $18.7 \mathrm{q}$ & $17.0 \mathrm{q}$ & $18.8 \mathrm{q}$ & $19.1 \mathrm{q}$ & $18.8 \mathrm{q}$ & \\
\hline 22 & $24.8 \mathrm{q}$ & $19.8 \mathrm{q}$ & $20.1 q$ & $20.8 q$ & $20.0 q$ & \\
\hline 23 & $23.7 q$ & $23.4 \mathrm{q}$ & $23.9 q$ & $23.6 q$ & $23.2 \mathrm{q}$ & \\
\hline 24 & $16.6 \mathrm{q}$ & $12.7 \mathrm{q}$ & $13.3 q$ & $13.3 q$ & $11.3 \mathrm{q}$ & \\
\hline 25 & $19.0 \mathrm{q}$ & $17.0 \mathrm{q}$ & $15.8 \mathrm{q}$ & $15.8 \mathrm{q}$ & & \\
\hline 26 & & $22.3 q$ & & & & \\
\hline 27 & $15.2 \mathrm{q}$ & $14.7 \mathrm{q}$ & $15.1 \mathrm{q}$ & $58.3 \mathrm{t}$ & $15.3 q$ & 17 \\
\hline $1^{\prime}$ & $109.0 \mathrm{~d}$ & $108.7 \mathrm{~d}$ & $109.2 \mathrm{~d}$ & $108.8 \mathrm{~d}$ & $108.4 \mathrm{~d}$ & \\
\hline $2^{\prime}$ & $83.0 \mathrm{~d}$ & $79.2 \mathrm{~d}$ & $78.8 \mathrm{~d}$ & $79.6 \mathrm{~d}$ & $79.4 \mathrm{~d}$ & \\
\hline
\end{tabular}

Table 3 Cytotoxicity of compounds 1 and 2 against tumor cell lines $\left(\mathrm{IC}_{50}, \mu \mathrm{g} \mathrm{ml}^{-1}\right)$

\begin{tabular}{lccc}
\hline & \multicolumn{3}{c}{ Compounds } \\
\cline { 2 - 3 } Cell lines & \multicolumn{1}{c}{} & \multicolumn{1}{c}{} \\
\hline A549 & 1.57 & 0.846 & Epothilone B \\
LOVO & 9.22 & 0.801 & 0.00249 \\
SKOV-3 & 27.06 & 15.47 & 0.0393 \\
\hline
\end{tabular}

bed volumes of $95 \%$ ethanol to obtain the ethanol eluent. The ethanol eluent was diluted to about $30 \%$ ethanol and subjected to a XAD-1600 resin column, eluting with 30, 40, 50, 60 and 70\% ethanol (each concentration eluted with two bed volumes). The eluents eluting with 60 and $70 \%$ ethanol were pooled and concentrated in vacuo at $50^{\circ} \mathrm{C}$ to give a mixture. The mixture was dissolved in $\mathrm{CHCl}_{3}$ and chromatographed on a silica gel column eluting with petroleum ether/acetone from 70:30-40:60, and fractions 1-4 were obtained on the basis of the TLC profiles. Analysis of fraction 1 by HPLC showed that it mainly contained epothilones A and B. Fractions 2-4 were subjected to a Sephadex LH-20 column (Pharmacia, Uppsala, sweden) and eluted with ethanol and detected by TLC to give subfraction 2, subfraction 3 and subfraction 4 , respectively. Subfraction 2 was further separated by semipreparative HPLC eluting with $\mathrm{MeOH} / \mathrm{H}_{2} \mathrm{O}$ (80:20) to give compound 3
( $t_{\mathrm{R}} 16.2 \mathrm{~min}, 21 \mathrm{mg}$ ). Subfraction 3 was also isolated by semi-preparative HPLC eluting with $\mathrm{MeOH} / \mathrm{CH}_{3} \mathrm{CN} / \mathrm{H}_{2} \mathrm{O}$ (35:10:55) to afford compounds $4\left(\mathrm{t}_{\mathrm{R}}\right.$ $22.8 \mathrm{~min}, 11 \mathrm{mg})$ and $\mathbf{5}\left(\mathrm{t}_{\mathrm{R}} 26.6 \mathrm{~min}, 8 \mathrm{mg}\right)$. Subfraction 4 was further purified by semi-preparative HPLC eluting with $\mathrm{CH}_{3} \mathrm{CN} / \mathrm{H}_{2} \mathrm{O}$ (45:55) to obtain compound 1 ( $\left.t_{R} 15.0 \mathrm{~min}, 55 \mathrm{mg}\right)$ and one collection $\left(t_{R} 17.0 \mathrm{~min}\right)$. The collection was further separated by semi-preparative HPLC eluting with $\mathrm{MeOH} / \mathrm{CH}_{3} \mathrm{CN} / \mathrm{H}_{2} \mathrm{O}$ (35:10:55) to give compound $2\left(\mathrm{t}_{\mathrm{R}} 28.1 \mathrm{~min}, 10 \mathrm{mg}\right)$.

Epothilone A 3- $\alpha$-D-arabinofuranoside (1). Colorless oil; $[\alpha] 25$ D-13.3 (c 0.3, EtOH); UV (EtOH) $\lambda_{\max } 249$ ( $\varepsilon$ 12083), 206 ( $\varepsilon$ 20416) nm; IR (KBr): $v_{\max } 3444,1738,1689 \mathrm{~cm}^{-1} ;{ }^{1} \mathrm{H}$ and ${ }^{13} \mathrm{C}$ NMR data, see Tables 1 and 2; ESIMS $\mathrm{m} / \mathrm{z} 626[\mathrm{M}+\mathrm{H}]^{+}, 648[\mathrm{M}+\mathrm{Na}]^{+}$; HRESIMS $\mathrm{m} / \mathrm{z} 648.2840[\mathrm{M}+\mathrm{Na}]^{+}$(calcd for $\left.\mathrm{C}_{31} \mathrm{H}_{47} \mathrm{NO}_{10} \mathrm{SNa}, 648.2818\right)$.

Epothilone B 3- $\alpha$-D-arabinofuranoside (2). Colorless oil; $[\alpha] 25$ D-3.57 (c 0.28, EtOH); UV (EtOH) $\lambda_{\max } 249$ ( $\varepsilon$ 10437), 212 ( $\varepsilon$ 13845) nm; IR (KBr): $v_{\max } 3455,1739,1689 \mathrm{~cm}^{-1} ;{ }^{1} \mathrm{H}$ and ${ }^{13} \mathrm{C}$ NMR data, see Tables 1 and 2; ESIMS $m / z 640[\mathrm{M}+\mathrm{H}]^{+}, 662[\mathrm{M}+\mathrm{Na}]^{+}$; HRESIMS $m / z 662.2982[\mathrm{M}+\mathrm{Na}]^{+}$ (calcd for $\mathrm{C}_{32} \mathrm{H}_{49} \mathrm{NO}_{10} \mathrm{SNa}, 662.2975$ ).

Epothilone D 3- $\alpha$-D-arabinofuranoside (3). Colorless oil; $[\alpha] 25$ D-27.4 (c 0.84, EtOH); UV (EtOH) $\lambda_{\max } 251$ ( $\varepsilon$ 16443), 213 ( $\varepsilon$ 20503) nm; IR (KBr): $v_{\max } 3457,1738,1687 \mathrm{~cm}^{-1} ;{ }^{1} \mathrm{H}$ and ${ }^{13} \mathrm{C}$ NMR data, see Tables 1 and 2; ESIMS $m / z 610[\mathrm{M}+\mathrm{H}]^{+}, 632[\mathrm{M}+\mathrm{Na}]^{+}$; HRESIMS $m / z 632.2895[\mathrm{M}+\mathrm{Na}]^{+}$ (calcd for $\mathrm{C}_{31} \mathrm{H}_{47} \mathrm{NO}_{9} \mathrm{SNa}, 632.2869$ ). 
Epothilone $C_{9}$ 3- $\alpha$-D-arabinofuranoside (4). Colorless oil; $[\alpha] 25$ D-26.2 (c 0.42, EtOH); UV (EtOH) $\lambda_{\max } 254$ ( $\varepsilon$ 10714), 209 ( $\varepsilon$ 9970) nm; IR (KBr): $v_{\max } 3446,1737,1688 \mathrm{~cm}^{-1} ;{ }^{1} \mathrm{H}$ and ${ }^{13} \mathrm{C}$ NMR data, see Tables 1 and 2 ; ESIMS $\mathrm{m} / \mathrm{z} 626[\mathrm{M}+\mathrm{H}]^{+}, 648[\mathrm{M}+\mathrm{Na}]^{+}$; HRESIMS $\mathrm{m} / z 648.2800[\mathrm{M}+\mathrm{Na}]^{+}$(calcd for $\left.\mathrm{C}_{31} \mathrm{H}_{47} \mathrm{NO}_{10} \mathrm{SNa}, 648.2818\right)$.

8-Demethyl epothilone A 3- $\alpha$-D-arabinofuranoside (5). Colorless oil; $[\alpha] 25$ $\mathrm{D}+7.9$ (c 1.13, EtOH); UV (EtOH) $\lambda_{\max } 250$ ( $\varepsilon$ 7087), 214 ( $\varepsilon$ 8798) nm; IR $(\mathrm{KBr}): v_{\max } 3438,1736,1690 \mathrm{~cm}^{-1} ;{ }^{1} \mathrm{H}$ and ${ }^{13} \mathrm{C}$ NMR data, see Tables 1 and 2 ; ESIMS $m / z 612[\mathrm{M}+\mathrm{H}]^{+}, 634[\mathrm{M}+\mathrm{Na}]^{+}$; HRESIMS $m / z 634.2681[\mathrm{M}+\mathrm{Na}]^{+}$ (calcd for $\mathrm{C}_{30} \mathrm{H}_{45} \mathrm{NO}_{10} \mathrm{SNa}, 634.2662$ ).

\section{Acid hydrolysis of 1}

Compound $1(4.4 \mathrm{mg})$. was dissolved in $1 \mathrm{M} \mathrm{HCl}(1 \mathrm{ml})$ and then heated at $80{ }^{\circ} \mathrm{C}$ for $4 \mathrm{~h}$. Aglycone was extracted with $\mathrm{CHCl}_{3}$ thrice, and the aqueous residue was evaporated under reduced pressure. The residue was compared with standard sugars of arabinose, ribose and xylose (Sigma, St Louis, MO, USA) using TLC [ $n$-butanol: $\left.\mathrm{CH}_{3} \mathrm{COOH}: \mathrm{H}_{2} \mathrm{O}=4: 1: 1\right]$ analysis, which showed the sugar $\left(R_{\mathrm{F}}=0.4\right)$ to be arabinose.

\section{Determination of the absolute configuration of arabinose}

The above drying aqueous residue was dissolved in pyridine $(0.1 \mathrm{ml})$ containing L-cysteine methyl ester hydrochloride $(1 \mathrm{mg})$ and heated at $60^{\circ} \mathrm{C}$ for $1 \mathrm{~h}$. Arylisothiocyanate $(1.2 \mu \mathrm{l})$ was added to the mixture, which was heated at $60^{\circ} \mathrm{C}$ for $1 \mathrm{~h}$. The reaction mixture was directly analyzed by reversed-phase HPLC on an ODS column $(4.6 \times 250 \mathrm{~mm})$ at $35^{\circ} \mathrm{C}$ with an isocratic elution of $25 \%$ $\mathrm{CH}_{3} \mathrm{CN}$ in $50 \mathrm{~mm} \mathrm{H}_{3} \mathrm{PO}_{4}$ for $30 \mathrm{~min}$ and a subsequent washing of the column with $90 \% \mathrm{CH}_{3} \mathrm{CN}$ at a flow rate of $0.8 \mathrm{ml} \mathrm{min}^{-1}$. Peaks were detected with an ultraviolet detector at $250 \mathrm{~nm}$. The peak of the reaction mixture was detected at $15.72 \mathrm{~min}$ (D-arabinose). Treated in the same manner, standard D-arabinose (Sigma) gave a peak at $15.76 \mathrm{~min}$ and L-arabinose (Sigma) gave a peak at $14.60 \mathrm{~min}$.

\section{Antitumor bioassays}

For cytotoxicity measurements, stock epothilonoside solutions were prepared at $100 \mu \mathrm{g} / \mathrm{ml}$ in dimethyl sulfoxide and stored at $-20^{\circ} \mathrm{C}$. Human lung carcinoma A549, large intestine cancer cells LOVO and Human Ovarian Cancer Cell Line SKOV-3 were obtained from the Institute of Biochemistry and Cell Biology, Shanghai, Chinese Academy of Sciences. All cell lines were routinely cultured in Dulbecco's modified Eagle's medium containing $10 \%$ calf serum at $37^{\circ} \mathrm{C}$ for $4 \mathrm{~h}$, in a humidified atmosphere of $5 \% \mathrm{CO}_{2}$ incubator. The adherent cells at their logarithmic growth stage were digested, and were inoculated onto a 96-well culture plate at a density of $1.0 \times 10^{4} /$ well for the determination of proliferation. Test samples ranging from $0.1-100 \mu \mathrm{g} \mathrm{ml}^{-1}$ in $100 \mu \mathrm{l}$ were added to cells in triplicate wells, and incubation was continued for $72 \mathrm{~h}$. Coloration substrate, cell counting kit-8 (CCK-8, Dojindo, Kumamoto, Japan), was added to the medium, followed by further incubation for $3 \mathrm{~h}$. Absorbance at $450 \mathrm{~nm}$ with a $600 \mathrm{~nm}$ reference was measured thereafter. Media and dimethyl sulfoxide control wells, in which compound was absent, were included in all the experiments in order to eliminate the influence of dimethyl sulfoxide. The inhibitory rate of cell proliferation was calculated by the following formula:

Growth inhibition $(\%)=\left[\mathrm{OD}_{\text {control }}-\mathrm{OD}_{\text {treated }}\right] / \mathrm{OD}_{\text {control }} \times 100 \%$.

The cytotoxicity of compound on tumor cells was expressed as $\mathrm{IC}_{50}$ values (the drug concentration reducing the absorbance in treated cells by $50 \%$, with respect to untreated cells) and was calculated by the LOGIT method.

${ }^{1} \mathrm{H}$ and ${ }^{13} \mathrm{C}$ NMR spectra of five new epothilone variants (1-5) are detailed in Supplementary information.

1 Höfle, G., Bedorf, N., Gerth, K. \& Reichenbach, H. (GBF). Epothilones, process for preparing the same and their use as medicaments and as plant protecting agents. D.E. 4,138,042, May 27 (1993).

2 Gerth, K., Bedorf, N., Höfle, G., Irschik, H. \& Reichenbach, H. Epothilons A and B: antifungal and cytotoxic compounds from Sorangium cellulosum (Myxobacteria). production, physico-chemical and biological properties. J. Antibiot. 49, 560-563 (1996)

3 Höfle, G. et al. Epothilone A and B-novel 16-membered macrolides with cytotoxic activity: isolation, crystal structures, and conformation in solution. Angew. Chem. Int. Ed. Engl. 35, 1567-1569 (1996).

4 Hardt, I. H. et al. New natural epothilones from Sorangium cellulosum, strains So ce90/ B2 and So ce90/D13: isolation, structure elucidation, and SAR studies. J. Nat. Prod. 64, 847-856 (2001).

5 Arslanian, R. L. et al. A new cytotoxic epothilone from modified polyketide synthases heterologously expressed in Myxococcus xanthus. J. Nat. Prod. 65, 1061-1064 (2002).

6 Starks, C. M., Zhou, Y., Liu, F. \& Licari, P. J. Isolation and characterization of new epothilone analogues from recombinant Myxococcus xanthus fermentations. J. Nat. Prod. 66, 1313-1317 (2003).

7 Nicolaou, K. C., Roschangar, F. \& Vourloumis, D. Chemical biology of epothilones. Angew. Chem. Int. Ed. Engl. 37, 2014-2045 (1998).

8 Dong, S. D. et al. Rapid access to epothilone analogs via semisynthetic degradation and reconstruction of epothilone D. Tetrahedron Lett. 45, 1945-1947 (2004).

9 Lee, J. J. \& Swain, S. M. The epothilones: translating from the laboratory to the clinic. Clin. Cancer Res. 14, 1618-1624 (2008).

10 Gong, G. L. et al. Mutation and a high-throughput screening method for improving the production of epothilones of Sorangium. J. Ind. Microbiol. Biotechnol. 34, 615-623 (2007).

11 Tanaka, T., Nakashima, T., Ueda, T., Tomii, K. \& Kouno, I. Facile discrimination of aldose enantiomers by reversed-phase HPLC. Chem. Pharm. Bull. 55, 899-901 (2007).

12 Gorin, P. A. J. \& Mazurek, M. Further studies on the assignment of signals in ${ }^{13} \mathrm{C}$ magnetic resonance spectra of aldoses and derived methyl glycosides. Can. J. Chem. 53, 1212-1223 (1975).

13 Wang, J. D. et al. HSO71, A new furan-type cytotoxic metabolite from Streptomyces sp. HS-HY-071. J. Antibiot. 61, 623-626 (2008).

14 Nicolaou, K. C. et al. Designed epothilones: solid phase synthesis on microtubes, tubulin assembly properties and cytotoxic action against taxol-resistant tumor cells. Angew. Chem. Int. Ed. Engl. 36, 2097-2103 (1997).

15 Nicolaou, K. C. et al. Probing the ring size of epothilones: total synthesis of [14]-, [15]-, [17]-, and [18]-epothilones A. Angew. Chem. Int. Ed. Engl. 37, 81-84 (1998).

16 Meng, D. et al. Remote effects in macrolide formation through ring-forming olefin metathesis: an application to the synthesis of fully active epothilone congeners. J. Am. Chem. Soc. 119, 2733-2734 (1997).

17 Erdélyi, M. et al. Conformational preferences of natural and C3-modified epothilones in aqueous solution. J. Med. Chem. 51, 1469-1473 (2008).

Supplementary Information accompanies the paper on The Journal of Antibiotics website (http://www.nature.com/ja) 